\title{
Discontinuous hydration alters seed germination under stress of two populations of cactus that occur in different ecosystems in Northeast Brazil
}

\author{
Ayslan T. Lima and Marcos V. Meiado* \\ Seed Physiology Laboratory, Department of Biosciences, Federal University of Sergipe, Av. Vereador Olímpio \\ Grande, s/n, Bloco D, Campus Professor Alberto Carvalho, Bairro Porto, Itabaiana, SE, Brasil
}

(Received 10 May 2017; accepted after revision 25 August 2017; first published online 28 September 2017)

\begin{abstract}
The water uptake by the seed in arid and semi-arid ecosystems may not be continuous, but may occur in hydration and dehydration cycles (HD). In order to investigate the benefits of discontinuous hydration on seed germination of Pilosocereus catingicola subsp. salvadorensis subjected to environmental stresses, an imbibition curve was determined and times $X, Y$ and $Z$ selected, corresponding to 25,50 and $75 \%$ of the first phase of imbibition, respectively. Seeds of two populations (Caatinga and Restinga) were subjected to 0, 1, 2 and $3 \mathrm{HD}$ cycles, with $48 \mathrm{~h}$ of dehydration. Water and saline stress responses were tested at five osmotic potentials $(0.0,-0.1,-0.3,-0.6$ and $-0.9 \mathrm{MPa})$. Discontinuous hydration provided greater tolerance to water and saline stress in the seeds from the Caatinga region. When the seeds were subjected to water stress, the reduction of the mean germination time (MGT) provided by HD cycles decreased with increasing concentration of the solution. In saline stress, the reduction of MGT was greater in the solutions with the highest concentrations. We conclude that the seeds of the same species collected from populations located in different ecosystems have different germination responses after passage through discontinuous hydration and HD cycles. This provides greater tolerance to environmental stresses but with different responses among populations.
\end{abstract}

Keywords: abiotic stresses, Cactaceae, germinability, hydration-dehydration cycles, seed memory, semi-arid, stress tolerance

\section{Introduction}

Seeds dehydrate during the final stages of their development and, therefore, need to absorb water from the

* Correspondence

Email: meiado@ufs.br ambient surroundings to rehydrate their tissues and start the germination process (Baskin and Baskin, 2014). This dehydration during seed production is a natural process that allows the seeds to reduce their metabolism before dispersal in the environment where they can remain viable for longer periods to subsequently germinate. However, depending on where the seed is dispersed, this rehydration event, which will result in seed germination, may be interrupted by a lack of water in the soil and when this occurs the seeds interrupt their germination process and begin to lose the absorbed water (Fenner and Thompson, 2005). This event of loss of water by the seeds during the germination process is observed more frequently in arid and semi-arid ecosystems because, in these regions, there is a water limitation in the soil and in the time that this resource is available for the seeds, even during the rainy periods (Meiado et al., 2012; Meiado, 2013).

Many species that occur in arid and semi-arid ecosystems, such as the Caatinga, a semi-arid ecosystem located in the Northeast of Brazil, produce and disperse seeds that germinate in the upper layers of the soil. In these environments, the seeds have water available for their imbibition process for a limited time, since the evaporation of water from the soil surface in these layers occurs rapidly (Meiado et al., 2012). As seen, the imbibition of the seeds in these arid and semiarid ecosystems cannot be continuous, but is subject to hydration and dehydration cycles (HD) (Meiado, 2013). According to Dubrovsky (1996, 1998), discontinuous hydration renders the seeds of native species a high rate of survival during desiccation, demonstrating that these seeds may have a hydration memory, caused by the imbibition process, which preserves the resulting characteristics of the prior hydration. The main advantages attributed to discontinuous hydration are related to the high rate of survival during desiccation and the significant increase in germinability, speed and uniformity of seed germination, as well as production of more vigorous seedlings (Dubrovsky, 
1996; 1998; Aragão et al., 2002; Sánchez Soto et al., 2005; Rito et al., 2009; Meiado, 2013).

Cacti are among the plants most widely distributed in arid and semi-arid ecosystems of the new world. The species of this family show considerable variation in shape, colour, size, structure and embryonic characteristics of the seeds (Rojas-Aréchiga and Vázquez-Yanes, 2000; Valiente-Banuet and Godínez-Alvarez, 2002). Most species of cacti have seeds that germinate on the soil surface and are well suited to water loss during the dry season (Dubrovsky, 1998). In Brazil 260 species occur, grouped into 39 genuses and Pilosocereus Byles \& Rowley is one of the most representative (Taylor and Zappi, 2004; Zappi et al., 2016). Most species of this genus have a columnar habit, being represented in the country by 29 species and 16 subspecies terrestrial and/or rupicolous (Zappi et al., 2016). Pilosocereus catingicola (Gürke) Byles \& G.D. Rowley subsp. salvadorensis (Werderm.) Zappi, popularly known in Brazil as 'facheiro', has columnar habit and occurs in three different ecosystems in the Northeast of Brazil: Caatinga, a tropical dry forest that covers about $10 \%$ of the national territory; Atlantic forest, a tropical rainforest in the eastern part of Brazil; and Restinga, a distinct type of tropical and subtropical coastal rainforest, found along a large part of the Brazilian coast (Meiado et al.; 2015a,b; Santos and Meiado, 2015). For this reason, the populations of this species are subject to different environmental conditions and abiotic factors during production and germination of the seeds, and may undergo discontinuous hydration that differs in the field.

According to Contreras-Quiroz et al. (2016), the presence of hydration memory in the seeds of Cactaceae depends on the climate and the microenvironment where the cacti occur, indicating that environmental conditions imposed on the parental plants influence the germination responses of the cacti seeds when subjected to discontinuous hydration. Thus to test the theory proposed by Contreras-Quiroz et al. (2016), two hypotheses were proposed in this study: (1) seeds of the same species collected from populations located in different ecosystems have a different germination response after passing through discontinuous hydration; (2) HD cycles provide greater tolerance to environmental stresses; however, the seed germination response is different between populations. The aim of this study was to determine the occurrence of hydration memory in seeds of two populations of $P$. catingicola subsp. salvadorensis from the Caatinga and Restinga and investigate the beneficial effects on the seed germination of two populations when subjected to environmental stresses.

\section{Materials and methods}

Ripe fruits of $P$. catingicola subsp. salvadorensis were collected in areas of Caatinga and Restinga in the state of
Sergipe, Northeast Brazil. The population of P. catingicola subsp. salvadorensis from Caatinga where the fruits were collected is located in areas near the SE Highway 206, in the Poço Redondo municipality. Caatinga is a tropical dry forest and this region consists of patches of seasonally dry forest and sclerophyll vegetation (sensu Pennington et al., 2000). The variation in vegetation structure of this ecosystem is conditioned by topography, by human disturbance and, more significantly, by the combination of the low average annual rainfall and soil attributes. Rainfall ranges from 240 to $900 \mathrm{~mm}$ per year and the soil ranges from moderately fertile, saline and shallow to deep sandy soil and impoverished soil (Sampaio, 1995). The population of Restinga is located at Aruana Beach, in the Aracaju municipality, a few metres from the sea. Restinga areas of the Atlantic Coast are found along almost the entire Brazilian coast and cover an area of $7900 \mathrm{~km}^{2}$. This area is characterized by sandy and saline land with direct influence from the sea, where herbaceous and shrub species are found, as well as some species of Cactaceae (Meiado et al., 2015a,b; Santos and Meiado, 2015).

About 30 fruits were collected in each population, one fruit per plant. After collection, the fruits were taken to the laboratory, where the fruits were manually opened and the seeds were placed to dry in plastic trays at room temperature until complete dehydration of the funicular pulp. After this procedure, the funicular dewatered pulp was manually removed from the seeds, which were then rinsed in running water and dried at room temperature $\left(25 \pm 2^{\circ} \mathrm{C}\right)$ and $85 \pm 5 \%$ relative humidity.

To evaluate the imbibition curve of this species, 250 seeds were used for each population divided into five replications of 50 seeds each. Initially, the seeds were weighed on an analytical balance and placed for imbibition in a sealed plastic recipient containing $10 \mathrm{ml}$ of distilled water, which were maintained in the laboratory at room temperature. Seeds were imbibed for 12 $\mathrm{h}$ and evaluated at $60 \mathrm{~min}$ intervals until stabilization of water uptake. For each evaluation, the seeds were removed from the water, blotted with paper and weighed again. The partial imbibition curve was estimated by the change of the seed biomass at the different intervals.

After the construction of the partial imbibition curve, three points on the curve were selected, which were designated as times $X, Y$ and $Z$, corresponding to 25,50 and $75 \%$ of the first phase of imbibition, respectively (Bewley, 1997). These intervals were selected due to the short period that rainwater is available for the seeds in the upper layers of soil, which represented, in this study, periods of hydration of the HD cycles. For each of the three selected hydration times, seeds of the two populations were subjected to 0, 1, 2 and $3 \mathrm{HD}$ cycles with times of dehydration of $48 \mathrm{~h}$ for all cycles, using 500 seeds of each population for each evaluated stress. 
In testing the response to water and saline stress on seed germination of two populations of $P$. catingicola subsp. salvadorensis after passing through the discontinuous hydration, solutions of commercial polyethylene glycol 6000 (PEG 6000) (Villela et al., 1991) and sodium chloride (Braccini et al., 1996) were used, respectively. The experiment was conducted by evaluating five osmotic potentials [0.0 (distilled water), -0.1 , $-0.3,-0.6$ and $-0.9 \mathrm{MPa}$ ] with four replications for each treatment (water or saline stress), containing 25 seeds per replication. Seeds were sown in 5-cm Petri dishes, containing a double layer of filter paper moistened with $3 \mathrm{ml}$ of solution. The Petri dishes were sealed with parafilm and maintained at $25^{\circ} \mathrm{C}$ and photoperiod of $12 \mathrm{~h}$. Radicle protrusion was considered to be the criterion for germinated seeds, and was assessed daily over a 60-day period.

Germination parameters were calculated with the GerminaQuant software (Marques et al., 2015), including germinability $(G, \%)$ and mean germination time [MGT $=\sum n_{i} . t_{i} / \sum n_{i}$, where $t_{i}$ is the period from the beginning of the experiment to the $i$ th observation (days) and $n_{i}$ is the number of germinated seeds in the time $i$ (not the cumulative number, but the number corresponding to the $i$ th observation)] (Gordon, 1971). Germinability data were standardized transformed by arcsine square root transformation before analysis. The normal distribution of the data and homogeneity of the variances were verified through the ShapiroWilk and Levene tests, respectively. The results were submitted to multiple factorial analyses of variance with four factors (population, hydration times, number of HD cycles and osmotic potential) and the means were compared a posteriori by Tukey's test (Ranal and Santana, 2006). All analyses were performed in the Statistica 13 program with $\alpha=5 \%$ (StatSoft, 2016).

\section{Results}

Seeds of the two populations of $P$. catingicola subsp. salvadorensis began to germinate on the fourth day of evaluation. Although the percentage of imbibition of the seeds from Caatinga (41\%) was higher than the percentage of imbibition of the seeds from Restinga (24\%), the first phase of imbibition of the two populations ended $8 \mathrm{~h}$ after the onset of germination. Thus according to the partial imbibition curve, the times $X, Y$ and $Z$ corresponded to 2, 4 and $6 \mathrm{~h}$, respectively. These were the hydration times used to subject the seeds of both populations to HD cycles.

Regardless of the stress treatment, seed germination of $P$. catingicola subsp. salvadorensis was favoured by the discontinuous hydration, for example, an increase of about $40 \%$ in the germinability of seeds collected in the Caatinga that have undergone two HD cycles in time $Z$ and were sown in distilled water $(0.0 \mathrm{MPa})$.
This improvement of the germination process indicated the presence of a hydration memory in the seeds of $P$. catingicola subsp. salvadorensis and, as will be seen below, the pattern of germination responses observed in this study differed among populations and the discontinuous hydration rendered the seeds increased tolerance to environmental stresses. In general, the discontinuous hydration provided a greater tolerance to water and saline stress in the seeds collected in the Caatinga.

The pattern of germination responses of the two populations of $P$. catingicola subsp. salvadorensis evaluated in this study showed significant differences when they were subjected to water stress (Table 3), indicating that the seed germination of the two populations was not similar (Fig. 1). Increased water potential significantly reduced seed germination of the two populations (Table 3). This reduction was more drastic in the population of the Restinga at 0.6 and $0.9 \mathrm{MPa}$ (Fig. 1). Furthermore, the discontinuous hydration conferred an increased tolerance of $P$. catingicola subsp. salvadorensis seeds collected in the Caatinga when they were subjected to water stress (Table 3). However, when the seeds were subjected to this type of abiotic stress, no significant differences were observed in the seed germination between the hydration times (Table 3). Moreover, HD cycles favoured the germination of seeds collected in the Caatinga when they were subjected to all water stress treatments, except a potential of $-0.9 \mathrm{MPa}$. On the other hand, the germinability of seeds collected in the Restinga was only favoured by HD cycles at higher concentrations of solutions. An increase of about $20-40 \%$ was observed of the germinability of this population that had passed through the HD cycles and, subsequently, were subjected to solutions of -0.6 and $-0.9 \mathrm{MPa}$, respectively (Fig. 1).

In addition, a significant increase in the MGT was observed when the seeds of $P$. catingicola subsp. salvadorensis were subjected to water stress (Table 3). However, a significant interaction between the factors population and osmotic potential in the analysis indicated that the MGT of the seeds from the two populations was affected differently by the water potentials. Furthermore, the discontinuous hydration provided a reduction in the MGT of the seeds under water stress (Table 3), especially those seeds collected in the Caatinga (Table 3). This same pattern was observed at times $X, Y$ and $Z$, with no significant differences between MGT in the three hydration times evaluated (Tables 1 and 3). The largest reduction in the MGT provided by HD cycles when the seeds were subjected to water stress (2.7 days) was observed, for example, when the seeds of the Caatinga were sown in -0.1 $\mathrm{MPa}$ solutions after having gone through three HD cycles in time $X$ (Table 1).

In the saline potential applied to seeds that had also undergone HD cycles, seed germination of $P$. catingicola 


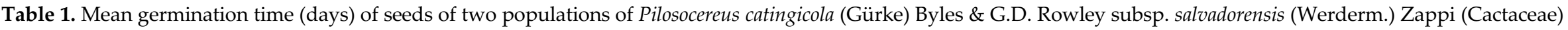
after having passed through discontinuous hydration and subjected to water stress

\begin{tabular}{|c|c|c|c|c|c|c|c|c|c|c|}
\hline \multirow[t]{2}{*}{ Time $X$} & \multicolumn{2}{|l|}{$0.0 \mathrm{MPa}$} & \multicolumn{2}{|l|}{$-0.1 \mathrm{MPa}$} & \multicolumn{2}{|l|}{$-0.3 \mathrm{MPa}$} & \multicolumn{2}{|l|}{$-0.6 \mathrm{MPa}$} & \multicolumn{2}{|l|}{$-0.9 \mathrm{MPa}$} \\
\hline & Caatinga & Restinga & Caatinga & Restinga & Caatinga & Restinga & Caatinga & Restinga & Caatinga & Restinga \\
\hline 0 cycle & $6.8 \pm 0.3 \mathrm{Aa}$ & $5.2 \pm 0.2 \mathrm{Ab}$ & $7.5 \pm 1.5 \mathrm{Aa}$ & $5.5 \pm 0.3 \mathrm{Ab}$ & $6.6 \pm 0.8 \mathrm{Aa}$ & $6.8 \pm 0.7 \mathrm{Aa}$ & $6.5 \pm 0.4 \mathrm{Aa}$ & $7.4 \pm 1.3 \mathrm{Aa}$ & - & $8.0 \pm 0.1 \mathrm{Aa}$ \\
\hline 1 cycle & $6.0 \pm 1.0 \mathrm{Ab}$ & $4.8 \pm 0.3 \mathrm{Ab}$ & $5.3 \pm 1.0 \mathrm{Bb}$ & $5.4 \pm 0.5 \mathrm{Ab}$ & $5.6 \pm 1.9 \mathrm{Ab}$ & $5.7 \pm 0.6 \mathrm{Ab}$ & $5.8 \pm 1.1 \mathrm{Ab}$ & $6.6 \pm 0.2 \mathrm{Aa}$ & $12.0 \pm 0.1 \mathrm{Aa}$ & $6.7 \pm 0.6 \mathrm{Ba}$ \\
\hline 2 cycles & $5.6 \pm 0.5 \mathrm{Ab}$ & $4.3 \pm 0.2 \mathrm{Bb}$ & $5.1 \pm 1.3 \mathrm{Bb}$ & $5.3 \pm 0.3 \mathrm{Ab}$ & $5.6 \pm 0.4 \mathrm{Ab}$ & $5.6 \pm 0.4 \mathrm{Ab}$ & $5.5 \pm 0.5 \mathrm{Ab}$ & $6.7 \pm 1.0 \mathrm{Aa}$ & $6.7 \pm 0.1 \mathrm{Ba}$ & $6.2 \pm 0.3 \mathrm{Ba}$ \\
\hline 3 cycles & $4.4 \pm 0.6 \mathrm{Bb}$ & $4.4 \pm 0.9 \mathrm{Bb}$ & $4.8 \pm 0.8 \mathrm{Bb}$ & $5.5 \pm 0.2 \mathrm{Ab}$ & $4.5 \pm 0.9 \mathrm{Bb}$ & $5.6 \pm 0.5 \mathrm{Ab}$ & $5.1 \pm 0.3 \mathrm{Ab}$ & $6.8 \pm 1.5 \mathrm{Aa}$ & $5.6 \pm 0.1 \mathrm{Ca}$ & $6.8 \pm 2.9 \mathrm{Ba}$ \\
\hline \multirow[t]{2}{*}{ Time $Y$} & \multicolumn{2}{|l|}{$0.0 \mathrm{MPa}$} & \multicolumn{2}{|l|}{$-0.1 \mathrm{MPa}$} & \multicolumn{2}{|l|}{$-0.3 \mathrm{MPa}$} & \multicolumn{2}{|l|}{$-0.6 \mathrm{MPa}$} & \multicolumn{2}{|l|}{$-0.9 \mathrm{MPa}$} \\
\hline & Caatinga & Restinga & Caatinga & Restinga & Caatinga & Restinga & Caatinga & Restinga & Caatinga & Restinga \\
\hline 0 cycle & $6.8 \pm 0.3 \mathrm{Aa}$ & $5.2 \pm 0.2 \mathrm{Ab}$ & $7.5 \pm 1.5 \mathrm{Aa}$ & $5.5 \pm 0.3 \mathrm{Ab}$ & $6.6 \pm 0.8 \mathrm{Aa}$ & $6.8 \pm 0.7 \mathrm{Aa}$ & $6.5 \pm 0.4 \mathrm{Aa}$ & $7.4 \pm 1.3 \mathrm{Aa}$ & - & $8.0 \pm 0.1 \mathrm{Aa}$ \\
\hline 1 cycle & $5.1 \pm 0.6 \mathrm{Bc}$ & $4.8 \pm 0.6 \mathrm{Aa}$ & $4.9 \pm 0.6 \mathrm{Bc}$ & $5.0 \pm 0.3 \mathrm{Aa}$ & $4.6 \pm 0.3 \mathrm{Bc}$ & $5.6 \pm 0.5 \mathrm{Bb}$ & $6.7 \pm 1.6 \mathrm{Ab}$ & $6.4 \pm 0.9 \mathrm{Aa}$ & $11.0 \pm 0.1 \mathrm{Aa}$ & $7.1 \pm 0.6 \mathrm{Ba}$ \\
\hline 2 cycles & $4.5 \pm 0.3 \mathrm{Bb}$ & $4.4 \pm 0.3 \mathrm{Bb}$ & $4.7 \pm 0.2 \mathrm{Bb}$ & $4.8 \pm 0.3 \mathrm{Ab}$ & $4.7 \pm 0.4 \mathrm{Bb}$ & $5.2 \pm 0.8 \mathrm{Bb}$ & $6.5 \pm 1.6 \mathrm{Ab}$ & $6.0 \pm 1.0 \mathrm{Ba}$ & $9.0 \pm 0.1 \mathrm{Ba}$ & $6.6 \pm 1.1 \mathrm{Ba}$ \\
\hline 3 cycles & $4.4 \pm 0.3 \mathrm{Ba}$ & $4.0 \pm 0.1 \mathrm{Bb}$ & $5.0 \pm 0.6 \mathrm{Ba}$ & $4.5 \pm 0.4 \mathrm{Ab}$ & $5.1 \pm 0.5 \mathrm{Ba}$ & $5.0 \pm 0.8 \mathrm{Ba}$ & $5.2 \pm 0.7 \mathrm{Ba}$ & $5.8 \pm 1.1 \mathrm{Ba}$ & $5.0 \pm 0.1 \mathrm{Ca}$ & $7.0 \pm 0.8 \mathrm{Ba}$ \\
\hline \multirow[t]{2}{*}{ Time $Z$} & \multicolumn{2}{|l|}{$0.0 \mathrm{MPa}$} & \multicolumn{2}{|l|}{$-0.1 \mathrm{MPa}$} & \multicolumn{2}{|l|}{$-0.3 \mathrm{MPa}$} & \multicolumn{2}{|l|}{$-0.6 \mathrm{MPa}$} & \multicolumn{2}{|l|}{$-0.9 \mathrm{MPa}$} \\
\hline & Caatinga & Restinga & Caatinga & Restinga & Caatinga & Restinga & Caatinga & Restinga & Caatinga & Restinga \\
\hline 0 cycle & $6.8 \pm 0.3 \mathrm{Aa}$ & $5.2 \pm 0.2 \mathrm{Ab}$ & $7.5 \pm 1.5 \mathrm{Aa}$ & $5.5 \pm 0.3 \mathrm{Ab}$ & $6.6 \pm 0.8 \mathrm{Aa}$ & $6.8 \pm 0.7 \mathrm{Aa}$ & $6.5 \pm 0.4 \mathrm{Aa}$ & $7.4 \pm 1.3 \mathrm{Aa}$ & - & $8.0 \pm 0.1 \mathrm{Aa}$ \\
\hline 1 cycle & $5.2 \pm 0.5 \mathrm{Ba}$ & $4.6 \pm 0.5 \mathrm{Ab}$ & $5.1 \pm 0.8 \mathrm{Ba}$ & $4.9 \pm 0.4 \mathrm{Ab}$ & $5.4 \pm 0.9 \mathrm{Aa}$ & $5.4 \pm 0.5 \mathrm{Bb}$ & $7.2 \pm 1.9 \mathrm{Aa}$ & $5.4 \pm 0.5 \mathrm{Bb}$ & $5.0 \pm 0.1 \mathrm{Ba}$ & $7.1 \pm 1.1 \mathrm{Aa}$ \\
\hline 2 cycles & $4.8 \pm 0.9 \mathrm{Bb}$ & $3.7 \pm 0.4 \mathrm{Bb}$ & $5.0 \pm 0.8 \mathrm{Bb}$ & $4.1 \pm 0.5 \mathrm{Bb}$ & $5.1 \pm 0.4 \mathrm{Ab}$ & $4.5 \pm 0.4 \mathrm{Bb}$ & $7.1 \pm 0.9 \mathrm{Aa}$ & $5.5 \pm 0.6 \mathrm{Bb}$ & $7.1 \pm 0.9 \mathrm{Aa}$ & $7.2 \pm 1.7 \mathrm{Aa}$ \\
\hline 3 cycles & $4.9 \pm 0.7 \mathrm{Bb}$ & $3.9 \pm 0.9 \mathrm{Bb}$ & $5.2 \pm 0.7 \mathrm{Bb}$ & $4.2 \pm 0.4 \mathrm{Bb}$ & $5.5 \pm 0.9 \mathrm{Ab}$ & $5.0 \pm 1.0 \mathrm{Ba}$ & $6.8 \pm 0.9 \mathrm{Aa}$ & $5.8 \pm 0.2 \mathrm{Ba}$ & $7.1 \pm 0.1 \mathrm{Aa}$ & $6.0 \pm 1.0 \mathrm{Aa}$ \\
\hline
\end{tabular}

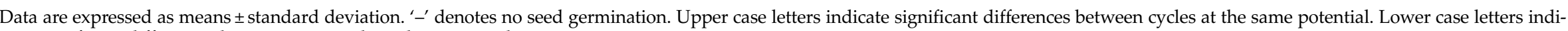
cate significant differences between potentials at the same cycle. 
Table 2. Mean germination time (days) of seeds of two populations of Pilosocereus catingicola (Gürke) Byles \& G.D. Rowley subsp. salvadorensis (Werderm.) Zappi (Cactaceae) after having passed through discontinuous hydration and subjected to water stress

\begin{tabular}{|c|c|c|c|c|c|c|c|c|c|c|}
\hline \multirow[t]{2}{*}{ Time $X$} & \multicolumn{2}{|l|}{$0.0 \mathrm{MPa}$} & \multicolumn{2}{|l|}{$-0.1 \mathrm{MPa}$} & \multicolumn{2}{|l|}{$-0.3 \mathrm{MPa}$} & \multicolumn{2}{|l|}{$-0.6 \mathrm{MPa}$} & \multicolumn{2}{|l|}{$-0.9 \mathrm{MPa}$} \\
\hline & Caatinga & Restinga & Caatinga & Restinga & Caatinga & Restinga & Caatinga & Restinga & Caatinga & Restinga \\
\hline 0 cycle & $6.5 \pm 0.4 \mathrm{Ab}$ & $6.0 \pm 1.4 \mathrm{Ab}$ & $6.5 \pm 0.9 \mathrm{Ab}$ & $7.8 \pm 0.6 \mathrm{Ab}$ & $6.7 \pm 1.1 \mathrm{Ab}$ & $8.1 \pm 1.1 \mathrm{Aa}$ & $10.1 \pm 1.1 \mathrm{Aa}$ & $10.0 \pm 0.1 \mathrm{Aa}$ & $10.5 \pm 0.4 \mathrm{Aa}$ & $12.5 \pm 0.6 \mathrm{Aa}$ \\
\hline 1 cycle & $4.5 \pm 0.3 \mathrm{Bb}$ & $3.8 \pm 0.3 \mathrm{Bb}$ & $4.9 \pm 0.4 \mathrm{Bb}$ & $4.0 \pm 0.4 \mathrm{Bb}$ & $5.1 \pm 0.1 \mathrm{Bb}$ & $4.3 \pm 0.9 \mathrm{Bb}$ & $8.3 \pm 0.9 \mathrm{Aa}$ & $5.7 \pm 0.2 \mathrm{Ba}$ & $10.0 \pm 1.1 \mathrm{Aa}$ & $6.7 \pm 1.0 \mathrm{Ba}$ \\
\hline 2 cycles & $4.1 \pm 0.3 \mathrm{Bb}$ & $3.8 \pm 0.6 \mathrm{Bb}$ & $4.3 \pm 0.2 \mathrm{Bb}$ & $3.8 \pm 0.6 \mathrm{Bb}$ & $4.9 \pm 0.3 \mathrm{Bb}$ & $4.0 \pm 1.1 \mathrm{Bb}$ & $8.4 \pm 0.8 \mathrm{Ba}$ & $5.1 \pm 0.2 \mathrm{Bb}$ & $10.2 \pm 2.2 \mathrm{Aa}$ & $6.8 \pm 0.6 \mathrm{Ba}$ \\
\hline 3 cycles & $4.0 \pm 0.2 \mathrm{Bb}$ & $3.6 \pm 0.4 \mathrm{Bb}$ & $4.3 \pm 0.4 \mathrm{Bb}$ & $3.7 \pm 0.3 \mathrm{Bb}$ & $5.0 \pm 0.8 \mathrm{Bb}$ & $3.6 \pm 0.5 \mathrm{Bb}$ & $7.4 \pm 0.7 \mathrm{Ba}$ & $4.7 \pm 0.5 \mathrm{Bb}$ & $9.4 \pm 2.0 \mathrm{Aa}$ & $6.1 \pm 2.2 \mathrm{Ba}$ \\
\hline \multirow[t]{2}{*}{ Time $Y$} & \multicolumn{2}{|l|}{$0.0 \mathrm{MPa}$} & \multicolumn{2}{|l|}{$-0.1 \mathrm{MPa}$} & \multicolumn{2}{|l|}{$-0.3 \mathrm{MPa}$} & \multicolumn{2}{|l|}{$-0.6 \mathrm{MPa}$} & \multicolumn{2}{|l|}{$-0.9 \mathrm{MPa}$} \\
\hline & Caatinga & Restinga & Caatinga & Restinga & Caatinga & Restinga & Caatinga & Restinga & Caatinga & Restinga \\
\hline 0 cycle & $6.5 \pm 0.4 \mathrm{Ab}$ & $6.0 \pm 1.4 \mathrm{Ab}$ & $6.5 \pm 0.9 \mathrm{Ab}$ & $7.8 \pm 0.6 \mathrm{Ab}$ & $6.7 \pm 1.1 \mathrm{Ab}$ & $8.1 \pm 1.1 \mathrm{Ab}$ & $10.1 \pm 1.1 \mathrm{Aa}$ & $10.0 \pm 0.1 \mathrm{Aa}$ & $10.5 \pm 0.4 \mathrm{Aa}$ & $12.5 \pm 0.6 \mathrm{Aa}$ \\
\hline 1 cycle & $4.6 \pm 0.3 \mathrm{Bb}$ & $3.9 \pm 0.2 \mathrm{Bc}$ & $4.8 \pm 0.1 \mathrm{Bb}$ & $5.2 \pm 0.5 \mathrm{Bb}$ & $5.0 \pm 0.5 \mathrm{Ab}$ & $4.2 \pm 0.5 \mathrm{BC}$ & $8.2 \pm 0.6 \mathrm{Ba}$ & $5.3 \pm 0.6 \mathrm{Bb}$ & $9.7 \pm 0.1 \mathrm{Aa}$ & $7.4 \pm 0.3 \mathrm{Ba}$ \\
\hline 2 cycles & $4.2 \pm 0.7 \mathrm{Bb}$ & $3.5 \pm 0.4 \mathrm{Bb}$ & $4.6 \pm 0.6 \mathrm{Bb}$ & $4.0 \pm 1.9 \mathrm{Bb}$ & $4.6 \pm 0.3 \mathrm{Bb}$ & $3.9 \pm 0.5 \mathrm{Bb}$ & $7.4 \pm 2.5 \mathrm{Ba}$ & $4.8 \pm 1.4 \mathrm{Bb}$ & $9.0 \pm 0.8 \mathrm{Aa}$ & $7.4 \pm 1.5 \mathrm{Ba}$ \\
\hline 3 cycles & $4.1 \pm 0.1 \mathrm{Bb}$ & $3.4 \pm 0.3 \mathrm{Bb}$ & $4.2 \pm 0.1 \mathrm{Bb}$ & $3.8 \pm 0.5 \mathrm{Cb}$ & $4.6 \pm 0.5 \mathrm{Bb}$ & $4.2 \pm 0.6 \mathrm{Bb}$ & $6.6 \pm 0.4 \mathrm{Ca}$ & $5.2 \pm 1.0 \mathrm{Ba}$ & $7.5 \pm 0.4 \mathrm{Ba}$ & $6.8 \pm 1.5 \mathrm{Ba}$ \\
\hline \multirow[t]{2}{*}{ Time $Z$} & \multicolumn{2}{|l|}{$0.0 \mathrm{MPa}$} & \multicolumn{2}{|l|}{$-0.1 \mathrm{MPa}$} & \multicolumn{2}{|l|}{$-0.3 \mathrm{MPa}$} & \multicolumn{2}{|l|}{$-0.6 \mathrm{MPa}$} & \multicolumn{2}{|l|}{$-0.9 \mathrm{MPa}$} \\
\hline & Caatinga & Restinga & Caatinga & Restinga & Caatinga & Restinga & Caatinga & Restinga & Caatinga & Restinga \\
\hline 0 cycle & $6.5 \pm 0.4 \mathrm{Ab}$ & $6.0 \pm 1.4 \mathrm{Ac}$ & $6.5 \pm 0.9 \mathrm{Ab}$ & $7.8 \pm 0.6 \mathrm{Ac}$ & $6.7 \pm 1.1 \mathrm{Ab}$ & $8.1 \pm 1.1 \mathrm{Ac}$ & $10.1 \pm 1.1 \mathrm{Aa}$ & $10.0 \pm 0.1 \mathrm{Ab}$ & $10.5 \pm 0.4 \mathrm{Aa}$ & $12.5 \pm 0.6 \mathrm{Aa}$ \\
\hline 1 cycle & $4.4 \pm 0.3 \mathrm{Bc}$ & $4.1 \pm 0.8 \mathrm{Bb}$ & $4.7 \pm 0.6 \mathrm{Bc}$ & $4.3 \pm 0.4 \mathrm{Bb}$ & $5.1 \pm 0.2 \mathrm{Bc}$ & $4.8 \pm 0.4 \mathrm{Bb}$ & $6.5 \pm 1.0 \mathrm{Bb}$ & $5.3 \pm 0.3 \mathrm{Bb}$ & $10.0 \pm 2.4 \mathrm{Aa}$ & $7.2 \pm 0.7 \mathrm{Ba}$ \\
\hline 2 cycles & $4.3 \pm 0.5 \mathrm{Bc}$ & $3.9 \pm 0.6 \mathrm{Bb}$ & $4.5 \pm 0.6 \mathrm{Bc}$ & $3.9 \pm 0.5 \mathrm{Bb}$ & $4.8 \pm 0.6 \mathrm{Bc}$ & $4.0 \pm 0.4 \mathrm{Bb}$ & $6.5 \pm 0.9 \mathrm{Bb}$ & $4.8 \pm 0.7 \mathrm{Bb}$ & $9.0 \pm 0.8 \mathrm{Aa}$ & $7.0 \pm 0.9 \mathrm{Ba}$ \\
\hline 3 cycles & $4.1 \pm 0.2 \mathrm{Bc}$ & $3.6 \pm 0.7 \mathrm{Bb}$ & $4.4 \pm 0.4 \mathrm{Bc}$ & $3.9 \pm 0.2 \mathrm{Bb}$ & $4.7 \pm 0.6 \mathrm{Bc}$ & $3.9 \pm 0.8 \mathrm{Bb}$ & $6.2 \pm 1.2 \mathrm{Bb}$ & $5.3 \pm 0.5 \mathrm{Ba}$ & $9.1 \pm 1.8 \mathrm{Aa}$ & $6.4 \pm 0.7 \mathrm{Ba}$ \\
\hline
\end{tabular}

Data are expressed as means \pm standard deviation. Upper case letters indicate significant differences between cycles at the same potential. Lower case letters indicate significant differences between potentials at the same cycle. 
Table 3. Results of the factorial ANOVA of the germinability and the mean germination time of seeds of two populations of Pilosocereus catingicola (Gürke) Byles \& G.D. Rowley subsp. salvadorensis (Werderm.) Zappi (Cactaceae) that had passed through discontinuous hydration and were subjected to water stress

\begin{tabular}{lrrr}
\hline Factors & $F$ & d.f. & \multicolumn{1}{c}{$P$} \\
\hline Germinability (\%) & & & \\
Population & 1122.005 & 1 & $<0.0001$ \\
Hydration times & 0.115 & 2 & 0.8912 \\
Number of HD cycles & 57.897 & 3 & $<0.0001$ \\
Osmotic potential & 481.615 & 4 & $<0.0001$ \\
Mean germination time (days) & & & \\
Population & 11.88 & 1 & 0.0006 \\
Hydration times & 2.55 & 2 & 0.0799 \\
Number of HD cycles & 67.66 & 3 & $<0.0001$ \\
Osmotic potential & 54.19 & 4 & $<0.0001$ \\
\hline
\end{tabular}

subsp. salvadorensis was favoured in both Caatinga and Restinga populations (Table 4). Passage through 1, 2 or 3 HD cycles increased the germinability compared with those seeds that had not gone through any cycle and were subjected to saline stress (Fig. 2). This increase provided by discontinuous hydration was observed in both populations (Table 4), with significant differences between the hydration times when the seeds were submitted to saline stress (Fig. 2 and Table 4).

The saline stress also resulted in an increase in the MGT of the seeds of $P$. catingicola subsp. salvadorensis (Table 4). However, the passage through HD cycles significantly reduced the MGT of seeds of the two populations that were subjected to this abiotic stress, with no significant differences between the hydration times evaluated in this study (Table 4). Although there were significant differences in the MGT between the two populations, the passage through the HD cycles increased the salt tolerance in the seeds of the Restinga population, mainly at more concentrated solutions, where the passage through three HD cycles in time $X$ was reduced by $4.5,5.3$ and 6.4 days when the seeds of this population were submitted to -0.3 , -0.6 and $-0.9 \mathrm{MPa}$ treatments, respectively (Tables 2 and 4).

\section{Discussion}

Discontinuous hydration is a process that occurs naturally in seeds that are produced and dispersed in arid and semi-arid environments where water is available for seed imbibition only briefly. Thus it is expected that seeds of native species naturally pass through HD cycles in the environment where these plants will be established (Allen and Meyer, 1998; Meiado, 2013). As seen in the results of this study, the passage through HD cycles favoured seed germination of the studied species and provided a greater tolerance to the abiotic stresses. Furthermore, the time that the seed remained in contact with water during the hydration cycles influenced the response of seeds subjected to salt stress. For the seeds of $P$. catingicola subsp. salvadorensis, cycles of $2 \mathrm{~h}$ benefited all measured germination parameters, indicating that shorter cycles are more favourable for this species, which should be related to the short time that water remains available for seed germination in the most superficial layers of the soil, even during the rainy season.

The water and saline stress in seeds of two populations of $P$. catingicola subsp. salvadorensis caused a reduction in seed germination with increasing osmotic concentrations of the solutions. This germination response was also observed in other species of Cactaceae subjected to these types of abiotic stresses (De la Barrera and Nobel, 2002; Ramírez-Padilla and Valverde, 2005; Meiado et al., 2010). Seeds of Cereus jamacaru DC. subsp. jamacaru also had a germination behaviour similar to the seeds of $P$. catingicola subsp. salvadorensis in conditions of water and saline stress. When the seeds of this species were subjected to water stress a reduction in germinability was observed with increasing concentrations of the PEG 6000 solutions, used to simulate water stress. This was not observed when seeds were germinated at lower osmotic potential (<-0.8 MPa) (Meiado et al., 2010). However, when the seeds of $C$. jamacaru subsp. jamacaru were subjected to saline stress there was also germination at all stress levels (up to $-1.0 \mathrm{MPa}$ ), as observed in this study. Meiado et al. (2010) attributed this different behaviour to the ability of the C. jamacaru subsp. jamacaru seeds to absorb the salt and store it or metabolize it for other purposes. Thus it is believed that the seeds of $P$. catingicola subsp. salvadorensis are also able to store or use the salt in a similar way and that is how they can germinate at high salt concentrations.

The increase in the seed germination of $P$. catingicola subsp. salvadorensis caused by HD cycles was also observed in seeds of other species of Cactaceae (Sánchez-Soto et al., 2005; Contreras-Quiroz et al., 2016) as well as in Helianthus annuus L. (Asteraceae), where germination reached $100 \%$ in seeds submitted to hydropriming and germinated in distilled water (0.0 MPa) (Kaya et al., 2006). In H. annuus, as well as in $P$. catingicola subsp. salvadorensis, there was also an increase in the percentage of germination of the seeds that had passed through HD cycles and were subjected to saline stress. However, Kaya et al. (2006) found that when these seeds were subjected to water stress after the HD cycles, seed germination of $H$. annuus was not favoured. Although discontinuous hydration has also favoured the seed germination of $P$. catingicola subsp. salvadorensis subjected to saline stress, especially in the population of the Restinga, the HD cycles also conferred greater tolerance to seeds of the Caatinga 

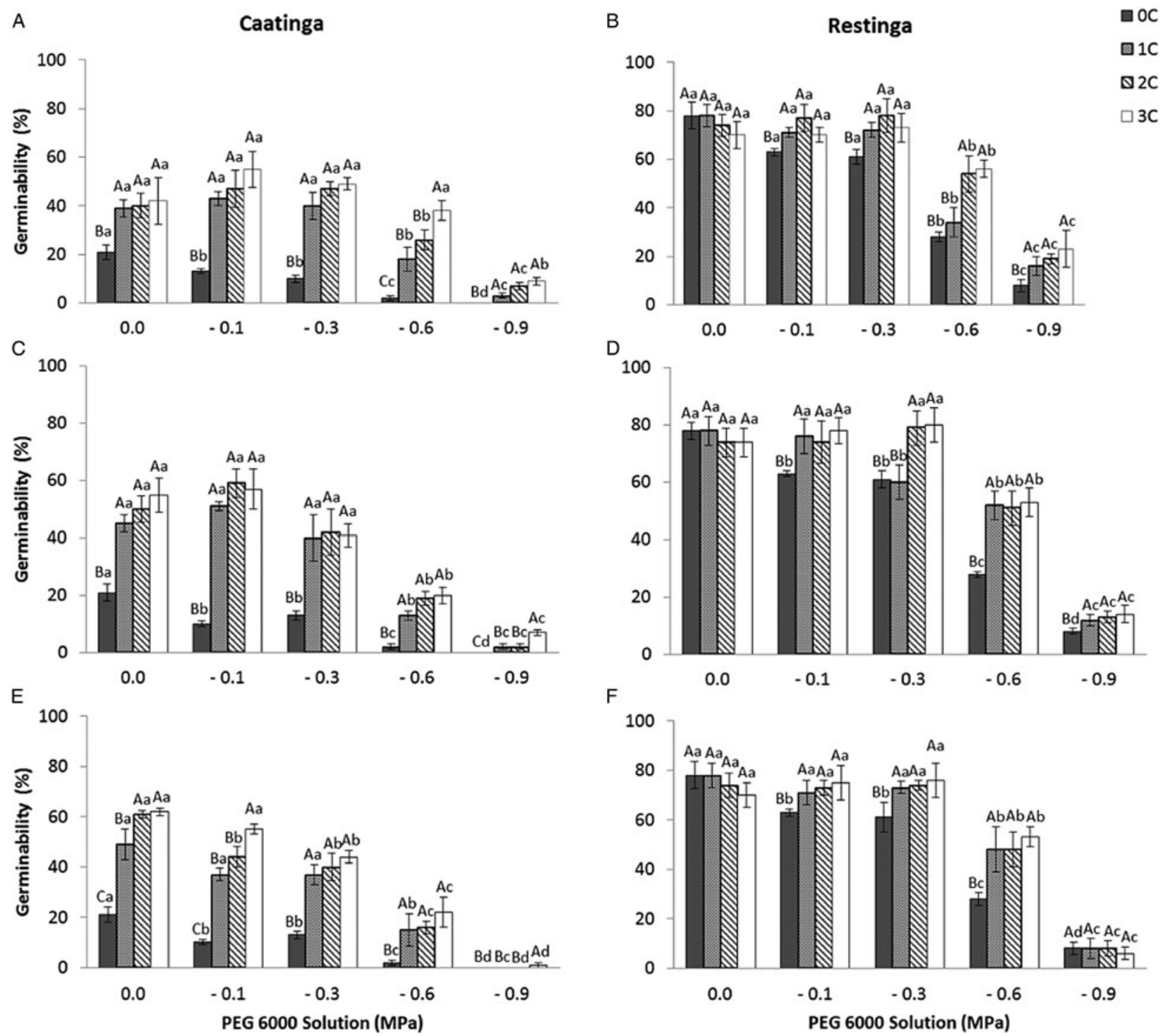

Figure 1. Germinability (\%) of seeds of two populations of Pilosocereus catingicola (Gürke) Byles \& G.D. Rowley subsp. salvadorensis (Werderm.) Zappi (Cactaceae) after passing through discontinuous hydration cycles (0, 1, 2 and 3 cycles) at times $X$ $(\mathrm{A}$ and $\mathrm{B}), Y(\mathrm{C}$ and $\mathrm{D})$ and $Z$ (E and F) and being subjected to water stress. Data are expressed as means \pm standard error. Upper case letters indicate significant differences between cycles at the same potential. Lower case letters indicate significant differences between potentials at the same cycle.

population when they were subjected to water stress. Thus two statements can be made after these comparisons: (1) the discontinuous hydration does not provide the same germination responses when the seeds are subjected to different environmental stresses and (2) the benefits that the HD cycles provide to the seeds may vary among species and especially among populations, corroborating the hypotheses of this study.

In some species seed germination is not favoured by discontinuous hydration. According to Aragão et al. (2002), HD cycles did not increase the percentage of seed germination of Phaseolus vulgaris L. (Fabaceae). However, other parameters of seed germination and seedling development were benefited after the passage of $P$. vulgaris seeds through $\mathrm{HD}$ cycles. According to the authors, the percentage of normal seedlings formed from seeds submitted to HD cycles was higher than those arising from seeds that were not submitted to discontinuous hydration, which was associated with a preimbibition of the seeds during the cycles that provided a higher rate of seedling emergence (Aragão et al., 2002).

Furthermore, the biochemistry of seed germination was changed with the passage of the seed through HD cycles, displaying higher contents of globulin and prola$\mathrm{min}$ in the seeds subjected to the cycles. Biochemical changes were also observed in seeds of Ferocactus peninsulae (F.A.C. Weber) Britton \& Rose var. townsendianus (Britton \& Rose) N.P. Taylor (Cactaceae) that had passed through HD cycles, showing a differential expression of RNA and several proteins related to primary metabolism, 
Table 4. Results of the factorial ANOVA of the germinability and the mean germination time of seeds of two populations of Pilosocereus catingicola (Gürke) Byles \& G.D. Rowley subsp. salvadorensis (Werderm.) Zappi (Cactaceae) that had passed through discontinuous hydration and were subjected to saline stress

\begin{tabular}{|c|c|c|c|}
\hline Factors & $F$ & d.f. & $P$ \\
\hline \multicolumn{4}{|l|}{ Germinability (\%) } \\
\hline Population & 7.021 & 1 & 0.0084 \\
\hline Hydration times & 3.775 & 2 & 0.0238 \\
\hline Number of HD cycles & 217.725 & 3 & $<0.0001$ \\
\hline Osmotic potential & 128.556 & 4 & $<0.0001$ \\
\hline \multicolumn{4}{|c|}{ Mean germination time (days) } \\
\hline Population & 76.24 & 1 & $<0.0001$ \\
\hline Hydration times & 1.18 & 2 & 0.2142 \\
\hline Number of HD cycles & 228.90 & 3 & $<0.0001$ \\
\hline Osmotic potential & 356.26 & 4 & $<0.0001$ \\
\hline
\end{tabular}

during discontinuous hydration (López-Urrutia et al., 2014). All these results indicate that the benefit provided by the discontinuous hydration can be evidenced at various stages of seed germination and seedling establishment, and reinforce the idea that different species are not benefiting similarly by discontinuous hydration.

Differential responses between species were also reported by Meiado (2013) in other seeds of the Caatinga. Trees from this semi-arid ecosystem produce seeds with slow and unsynchronized germination, such as Syagrus coronata (Mart.) Becc. (Arecaceae), display seed germination parameters that benefit from discontinuous hydration (i.e. G, MGT, Emergence Rate Index and Coefficient of Uniformity of Germination), such as rapid and synchronized germination in the field (Meiado, 2013). However, species with rapid and synchronized germination, such as Enterolobium contortisiliquum (Vell.) Morong (Fabaceae), produce more vigorous seedlings in the field after passage through HD cycles, but germinability is not favoured by discontinuous hydration (Meiado, 2013).

As seen in this study, some germination parameters, besides germinability, may also be favoured by discontinuous hydration (Dubrovsky, 1996, 1998; Meiado, 2013). As in P. catingicola subsp. salvadorensis, Patanè et al. (2008) observed in seeds of Sorghum bicolor (L.) Moench (Poaceae) an increase in the MGT as the salt concentration was increased in the solutions. However, in the present study, the HD cycles resulted in a more rapid germination for the seeds subjected to $\mathrm{NaCl}$ and PEG 6000 solutions, especially at low osmotic potential. Moreover, the MGT of the seeds increased with the decrease in osmotic potential, in both solutions of $\mathrm{NaCl}$ and PEG 6000. However, the solutions that simulated water stress caused a delay in seed germination of the species studied, compared with $\mathrm{NaCl}$ solutions, indicating a greater tolerance to saline stress by the cactus studied.
Different populations of the same species may have different germination behaviour when germinated under different environmental stresses, such as extreme temperatures, water availability and salinity (Leal et al., 2013; Meiado et al., 2016). These differences observed may be related to environmental characteristics where the parental plants produce their seeds (Baskin and Baskin, 2014; Contreras-Quiroz et al., 2016). Seeds of $P$. catingicola subsp. salvadorensis collected in the Caatinga which passed through discontinuous hydration showed a greater tolerance to water stress, while the seeds of the same species collected in the population of Restinga were more tolerant to saline stress after passing through the HD cycles, indicating a differential germinative behaviour between these two populations.

This type of germination response observed in the studied populations is justified by the fact that the cacti that occur in Restinga are very close to the sea, where they are subjected to conditions of greater salinity than the individuals of the Caatinga that, in turn, have the availability of water in the soil as the main limiting factor for the seed germination and establishment of new plants. These findings corroborate those of Contreras-Quiroz et al. (2016), who stated that the presence of hydration memory in cactus seeds depends on the climate or microenvironment where the species occurs. On the other hand, there are species with higher plasticity and seeds from different populations may have the same pattern of germination response when they are exposed to water or saline stress. Such a similar pattern was observed by Leal et al. (2013) in seeds of Calotropis procera (Ait.) R.Br. (Apocynaceae) of populations established in the same ecosystems evaluated in this study and, according to the authors, this is due to the fact that $C$. procera is an invasive species tolerant to various environmental stresses and that can invade and establish themselves similarly in the Caatinga and Restinga.

The Restinga seed lot used for the water potential experiment had a higher germinability than that used for the saline stress experiment. The difference between the seed sub-lots observed in this study is associated with some characteristics of the species:

(1) the species has a wide distribution in the Northeast region of Brazil and its populations are very large and composed of hundreds of individuals (Zappi et al., 2016);

(2) the species is self-incompatible and allogamous. Thus the formation of their seeds is conditioned to cross-pollination between different plants, increasing the genetic variation of populations (Rocha et al., 2007);

(3) there are many individuals in the areas where seeds were collected with different ages and this characteristic influenced the production (quantity) and 
A

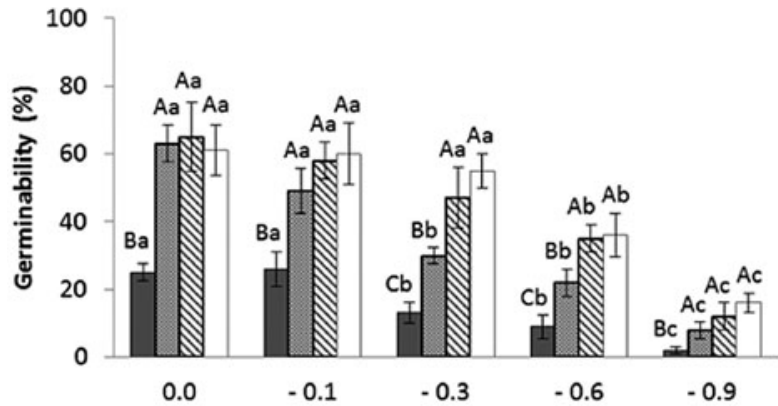

C 100

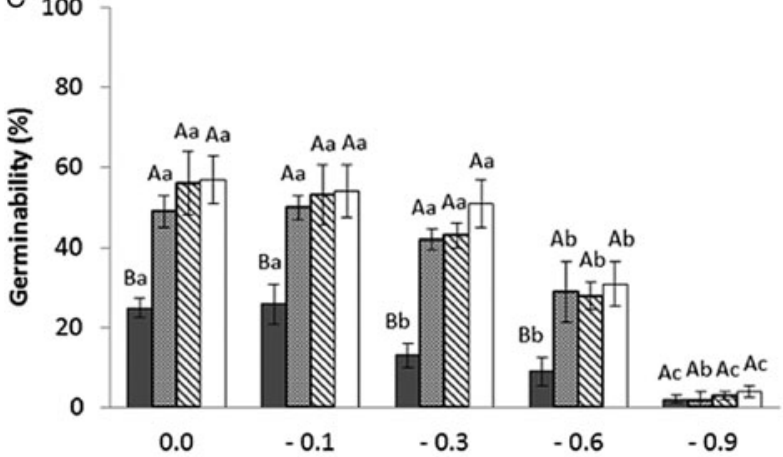

E 100

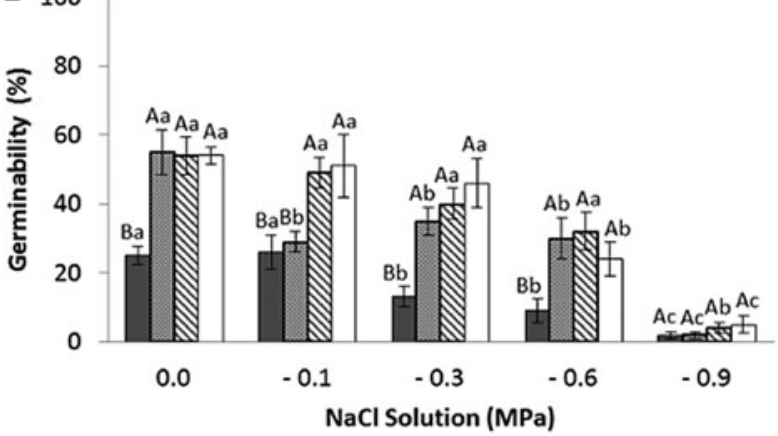

B

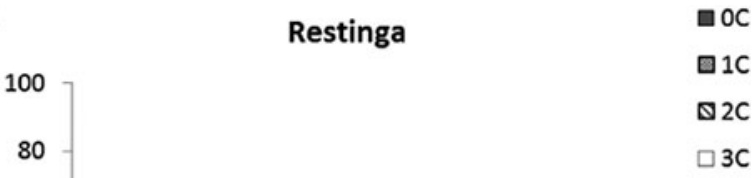

$\square \mathrm{OC}$

$\Delta 2 \mathrm{C}$

$\square 3 \mathrm{C}$

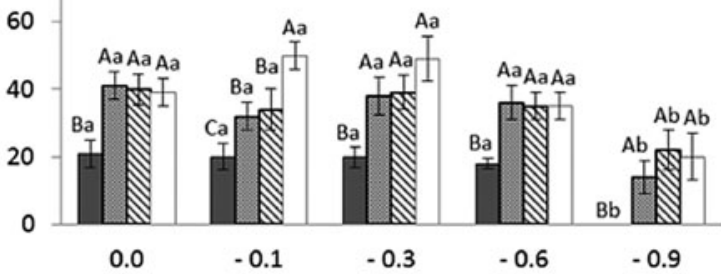

D 100

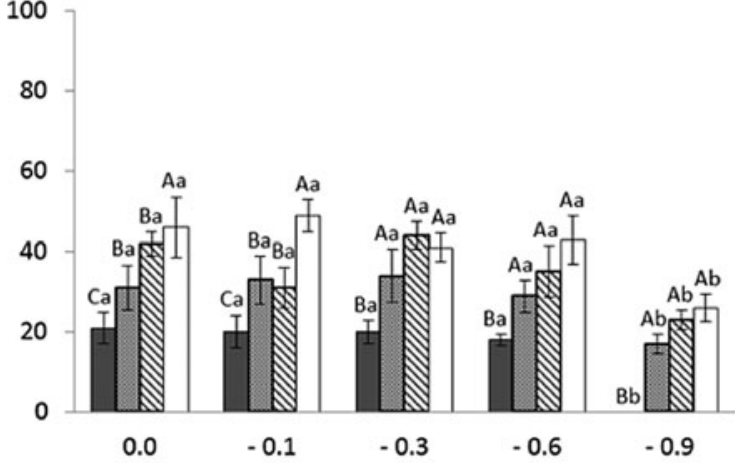

F 100

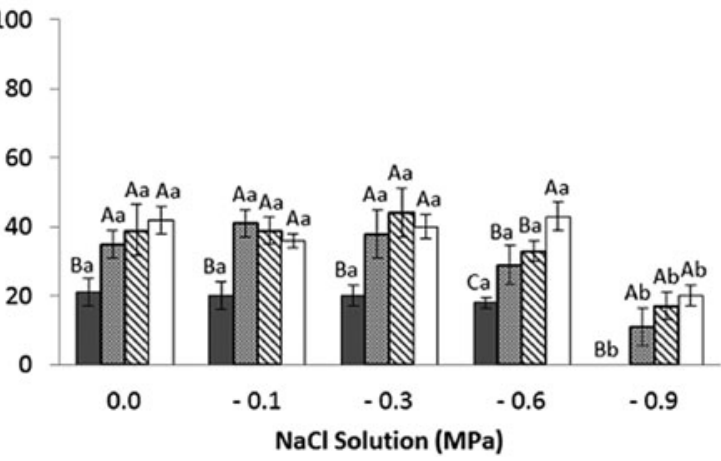

Figure 2. Germinability (\%) of seeds of two populations of Pilosocereus catingicola (Gürke) Byles \& G.D. Rowley subsp. salvadorensis (Werderm.) Zappi (Cactaceae) after passing through discontinuous hydration cycles (0, 1, 2 and 3 cycles) at times $X$ (A and B), $Y(C$ and $D)$ and $Z(E$ and $F)$ and being subjected to saline stress. Data are expressed as means \pm standard error. Upper case letters indicate significant differences between cycles at the same potential. Lower case letters indicate significant differences between potentials at the same cycle.

the germinative behaviour (quality) of the seed lots collected;

(4) the individuals bloom and produce fruits and seeds at different times throughout the year, being exposed to different conditions during their reproductive period.

All these characteristics together result in the collection of seed lots from the same population with different germination behaviour. In other words, seed sub-lots from the same population were collected from different individuals and that presented differentiatal germinative behaviour.

In conclusion, some notes should be made to update our knowledge on the influence of discontinuous hydration in the seeds of forest species, with special attention on cacti seeds. First, studies performed in the laboratory that evaluate the influence of abiotic factors on the seed germination of native species and characterize their tolerance and their patterns of germination responses without the passage of the seeds through discontinuous hydration should be considered with caution, since it does not demonstrate the true tolerance to environmental stresses that some native species present in the field, after the natural passage through discontinuous hydration. Secondly, the HD cycles can confer an increase of the tolerance to environmental stresses, but they provide different responses when the seeds of native species pass through cycles and then are subjected to different stresses. Thirdly, different hydration times of the HD cycles may give different germination responses when the 
seeds of native species are subjected to environmental stresses after passing through discontinuous hydration. Finally, this study reinforces the theory proposed by Contreras-Quiroz et al. (2016) that the hydration memory of cacti seeds depends on the climate and the microenvironment where the species are established, because populations of the same species occurring in different ecosystems showed different germination responses after passing through HD cycles, demonstrating that environmental characteristics are essential in determining the response of seeds to discontinuous hydration.

\section{Acknowledgements}

We thank to National Counsel of Technological and Scientific Development (CNPq) for the financial support.

\section{Financial support}

Financial support was provided by National Counsel of Technological and Scientific Development (CNPq).

\section{Conflicts of interest}

None.

\section{References}

Aragão, C.A., Dantas, B.F., Alves, E. and Corrêa, M.F. (2002) Sementes de feijão submetidas a ciclos e períodos de hidratação e secagem. Scientia Agricola 59, 87-92.

Baskin, C.C. and Baskin, J.M. (2014) Seeds: Ecology, Biogeography, and Evolution of Dormancy and Germination. San Diego, Academic Press.

Bewley, J.D. (1997) Seed germination and dormancy. The Plant Cell 9, 1055-1066.

Braccini, A.L., Ruiz, H.A., Braccini, M.C.L. and Reis, M.S. (1996). Germinação e vigor de sementes de soja sob estresse hídrico induzido por soluções de cloreto de sódio, manitol e polietileno glicol. Revista Brasileira de Sementes 18, 10-16.

Contreras-Quiroz, M., Pando-Moreno, M., Jurado, E., Flores, J., Bauk, K. and Gurvich, D.E. (2016) Is seed hydration memory dependent on climate? Testing this hypothesis with Mexican and Argentinian cacti species. Journal of Arid Environments 130, 94-97.

De la Barrera, E. and Nobel, P.S. (2002) Physiological ecology of seed germination for the columnar cactus Stenocereus queretaroensis. Journal of Arid Environments 53, 297-306.

Dubrovsky, J.G. (1996) Seed hydration memory in Sonoran Desert cacti and its ecological implication. American Journal of Botany 83, 624-632.

Dubrovsky, J.G. (1998). Discontinuous hydration as a facultative requirement for seed germination in two cactus species of the Sonoran Desert. Journal of the Torrey Botanical Society 125, 33-39.

Fenner, M. and Thompson, K. (2005) The Ecology of Seeds. Cambridge, Cambridge University Press.

Gordon, A.G. (1971) The germination resistance test - a new test for measuring germination quality of cereals. Canadian Journal of Plant Science 51, 181-183.

Kaya, M.D., Okçu, G., Atak, M., Çikili, Y. and Kolsarici, Ö. (2006) Seed treatment to overcome salt and drought stress during germination in sunflower (Helianthus annuus L.). European Journal of Agronomy 24, 291-295.

Leal, L.C., Meiado, M.V., Lopes, A.V. and Leal, I.R. (2013) Germination responses of the invasive Calotropis procera (Ait.) R.Br. (Apocynaceae): comparisons with seeds from two ecosystems in northeastern Brazil. Anais da Academia Brasileira de Ciências 85, 1025-1034.

López-Urrutia, E., Martínez-García, M., Monsalvo-Reyes, A., Salazar-Rojas, V., Montoya, R. and Campos, J.E. (2014) Differential RNA- and protein-expression profiles of cactus seeds capable of hydration memory. Seed Science Research 24, 91-99.

Marques, F.R.F., Meiado, M.V., Castro, N.M.C.R., Campos, M.L.O., Mendes, K.R., Santos, O.O. and Pompelli, M.F. (2015) GerminaQuant: a new tool for germination measurements. Journal of Seed Science 37, 248-255.

Meiado, M.V. (2013) Evidências de memória hídrica em sementes da Caatinga, pp. 89-94 in Stelmann, J.R., Isaias, R.M.S., Modolo, L.V., Vale, F.H.A. and Salino, A. (eds), Anais do $64^{\circ}$ Congresso Nacional de Botânica: botânica sempre viva. Belo Horizonte, Sociedade Botânica do Brasil.

Meiado, M.V., Albuquerque, L.S.C., Rocha, E.A. and Leal, I.R. (2008) Efeito da luz e da temperatura na germinação de sementes de Pilosocereus catingicola subsp. salvadorensis (Werderm.) Zappi (Cactaceae). Boletín de la Sociedad Latinoamericana y del Caribe de Cactáceas y otras Suculentas 5, 9-12.

Meiado, M.V., Albuquerque, L.S.C., Rocha, E.A., Rojas-Aréchiga, M. and Leal, I.R. (2010) Seed germination responses of Cereus jamacaru DC. ssp. jamacaru (Cactaceae) to environmental factors. Plant Species Biology 25, 120-128.

Meiado, M.V., Aona, L.Y.S., Nascimento, J.P.B., Lima, A.T. and Zappi, D.C. (2015a) Cactaceae, pp. 115-142 in Prata, A.P.N., Farias, M.C.V. and Landim, M.F. (eds), Flora de Sergipe. Vol. 2. Aracaju, Gráfica Editora Triunfo.

Meiado, M.V., Rojas-Aréchiga, M., Siqueira-Filho, J.A. and Leal, I.R. (2016) Effects of light and temperature on seed germination of cacti of Brazilian ecosystems. Plant Species Biology 31, 87-97.

Meiado, M.V., Machado, M.C., Zappi, D.C., Taylor, N.P. and Siqueira-Filho, J.A. (2015b) Cacti of the São Francisco watershed: ecological attributes, geographic distribution and endemism. Gaia Scientia 9, 40-53.

Meiado, M.V., Silva, F.F.S., Barbosa, D.C.A. and Siqueira Filho, J.A. (2012) Diaspores of the Caatinga: a review, pp. 306-365 in Siqueira Filho, J.A. (ed), Flora of the Caatingas of the São Francisco River - Natural History and Conservation. Rio de Janeiro, Andrea Jakobsson Estúdio.

Patanè, C., Cavallaro, V. and Cosentino, S.L. (2008) Germination and radicle growth in unprimed and primed seeds of sweet sorghum as affected by reduced water potential in $\mathrm{NaCl}$ at different temperatures. Industrial Crop and Products 30, 1-8. 
Pennington, R.T., Prado, D.E. and Pendry, C.A. (2000) Neotropical seasonally dry forests and quaternary vegetation changes. Journal of Biogeography 27, 261-273.

Ramírez-Padilla, C.A. and Valverde, T. (2005) Germination responses of three congeneric cactus species (Neobuxbaumia) with differing degrees of rarity. Journal of Arid Environments 61, 333-343.

Ranal, M.A. and Santana, D.G. (2006) How and why to measure the germination process? Revista Brasileira de Botânica 29, 1-11.

Rito, K.F., Rocha, E.A., Leal, I.R. and Meiado, M.V. (2009) As sementes de mandacaru têm memória hídrica? Boletín de la Sociedad Latinoamericana y del Caribe de Cactáceas y otras Suculentas 6, 26-31.

Rocha, E.A., Machado, I.C., Zappi, D. (2007) Fenologia, biologia da polinização e da reprodução de Pilosocereus Byles \& Rowley (Cactaceae) no Nordeste do Brasil. Boletín de la Sociedad Latinoamericana y del Caribe de Cactáceas y otras Suculentas 4, 5-7.

Rojas-Aréchiga, M. and Vázquez-Yanes, C. (2000) Cactus seed germination: a review. Journal of Arid Environments 44, 85-104.

Sampaio, E.V.S.B. (1995) Overview of the Brazilian Caatinga, pp. 35-63 in Bullock, S.H., Mooney, H.A. and Medina, E. (eds), Seasonal Dry Tropical Forests. Cambridge, Cambridge University Press.
Sánchez Soto, B.H., García Moya, E., Terrazas, T. and Reys Olivas, A. (2005) Efecto de la hidratación discontinua sobre la germinación de tres cactáceas del desierto costero de Topolobambo, Ahome, Sinaloa. Cactáceas y Suculentas Mexicanas 50, 4-14.

Santos, C.S. and Meiado, M.V. (2015) Levantamento florístico e status de conservação dos cactos do Estado de Sergipe, Nordeste do Brasil. Gaia Scientia 9, 136-146.

StatSoft (2016) Statistica 13. StatSoft South America. Available at: http://www.statsoft.com.br (accessed 21 May 2016).

Taylor, N.P. and Zappi, D.C. (2004) Cacti of Eastern Brazil. Kew, Royal Botanic Gardens.

Valiente-Banuet, A. and Godínez-Alvarez, H. (2002) Population and community ecology, pp. 91-108 in Nobel, P.S. (ed), Cacti: Biology and Uses. Los Angeles, University of California Press.

Villela, F.A., Doni Filho, L. and Sequeira, E.L. (1991) Tabela de potencial osmótico em função da concentração de Polietileno Glicol 6.000 e da temperatura. Pesquisa Agropecuária Brasileira 26, 1957-1968.

Zappi, D., Taylor, N., Santos, M.R. and Larocca, J. (2016) Cactaceae. Lista de espécies da flora do Brasil. Rio de Janeiro, Jardim Botânico do Rio de Janeiro. Available at: http://floradobrasil.jbrj.gov.br/jabot/floradobrasil/FB70 (accessed 21 May 2016). 